\title{
Anti-Corruption Education (PAK) Teaching Materials Based on Local Character in Social Science Subjects (IPS) to Build Anti-Corruption Culture for Young Generation in Surabaya
}

\author{
$1^{\text {st }}$ I Made Suwanda \\ Department of Pancasila and Citizenship \\ Education \\ University Negeri Surabaya \\ Surabaya, Indonesia \\ Email: imadeswanda@gmail.com
}

\author{
$4^{\text {th }}$ Murtiningsih \\ State Junior High School 43 \\ Surabaya, Indonesia \\ Email: Murtiningsih2010@gmail.com
}

\author{
$2^{\text {nd }}$ Sarmini \\ Department of Pancasila and Citizenship \\ Education \\ University Negeri Surabaya \\ Surabaya, Indonesia \\ Email: sarmini@unesa.ac.id
}

\author{
$5^{\text {th }}$ Misbakhun \\ State Junior High School 07 \\ Surabaya, Indonesia \\ Email: mbahblack@gmail.com
}

\author{
$3^{\text {rd }}$ Listyaningsih \\ Department of Pancasila and Citizenship \\ Education \\ University Negeri Surabaya \\ Surabaya, Indonesia \\ Email: Listiyaningsih@unesa.ac.id
}

\author{
$6^{\text {th }}$ Nor Chomariyah \\ State Junior High School 60 \\ Surabaya, Indonesia \\ Email: Norchomariyahsmpn18@gmail.com
}

\begin{abstract}
Teaching materials are important elements in the achievement of learning objectives, including anticorruption education. In order to ensure the quality of teaching materials, researchers conducted a trial of the feasibility of teaching materials that have been developed regarding anticorruption education based on local culture in social studies subjects in the younger generation in Surabaya. This research is descriptive qualitative. The population comes from $62 \mathrm{high}$ schools in Surabaya, with sample selection based on area juniorsampling. Data analysis techniques using descriptive statistics using percentages. The results found were anticorruption teaching materials developed in terms of content, linguistic feasibility, presentation of teaching materials, and very good quality graphics. So that it can be used as a guide for social studies teachers to build an anti-corruption culture for junior high school students in Surabaya. The recommendations of this study are aimed at schools and teachers in order to be able to develop anti-corruption culture of students through local character-based teaching materials that have been developed.
\end{abstract}

Keywords-Anti-Corruption Education, Local Character, IPS, Anti-Corruption Culture

\section{INTRODUCTION}

Corruption is a profit-seeking phenomenon through the abuse of power that occurs in various countries. Most community leaders who have power tend to be ambitious to increase personal gain by controlling access to state revenue through misuse of policy implementation [1]. Corruption is considered a relevant factor explaining democratic attitudes and behavior of a country. Characteristics of individuals in the state form patterns of interaction and political behavior with a background in the high level of education undertaken by participants. There is a positive relationship between the level of education, political participation, political knowledge, with the level of corruption [2]. The level of income per capita of a country also has a relationship with corruption that affects economic development in all countries. Low-to-middle income countries experience an increase in corruption cases, but increasingly sophisticated state development stages can reduce the level of corruption substantially [3].

Corruption has become a culture that has always existed from generation to generation. The level of future fraud and corruption in the economy is explicitly related to the level of fraud and corruption in the past [4]. Other adverse effects of corruption hamper the pace of economic growth, result in loss of income, demoralize the government, weaken all efforts to formulate policies, reduce service quality, cause fiscal pressure, threaten economic development and undermine people's trust and expectations [5]-[7]. The existence of acts of corruption is very difficult to detect in a decentralized authoritarian system called the mandate rule. Officials in China must prioritize political targets above the policy of implementing laws regarding the relative standards for corruption [8].

Corruption results in huge losses for the country's economic development. Based on 476 municipalities in Brazil it was found that corruption had an impact on GDP which decreased by about $18 \%$ per capita [9]. Multinational companies are at risk of experiencing difficulties in conducting international business due to corruption. Acts of corruption cause a reduction in the level of production activity as a revenue producer of up to $50 \%$ in the agricultural and trade sectors in rural Liberia [10]. Besides impacting on economic problems, corruption also has an impact on living standards and health services. Based on the 
Corruption Perception Index provided by the Transperancy International Index and the Human Development Index by the United Nations shows a negative relationship between human development and corruption. Countries with relatively high levels of corruption tend to have poor health services and a low standard of living [11].

Corrupt leaders undermine the main economic activities of the community led [12]. There is no definite reason why a corruption leader. It is possible that the reasons for corruption for personal gain, or use them to strengthen their position in the existing patron-client network. Corruption by the government has a negative effect on economic growth on capital liberalization accounts, including in thirteen AsiaPacific countries during the period 1997-2013 [13], [14]. More than 180,000 government officials received disciplinary sentences in China. Most corrupt politicians win public support if they are able to reciprocate in the form of large economic benefits to citizens, and effectively enhance economic development. Thus, citizens are able to tolerate acts of corruption committed [15].

Various anti-corruption activities have been carried out in various countries. New York City and the state of Victoria in Australia design anti-corruption measures by classifying and characterizing the nature and type of corruption activities [16]. Khazakstan implemented the "Greasing The Wheels" program, the code of ethics for FCPA compliance guidelines, and anti-corruption compliance programs as a platform for corporate governance policies to help avoid costly penalties and investigations in an effort to overcome violations of Foreign Corrupt Practicea Art (FCPA) [17]. While India launched a bribe site platform as a search engine for corrupt officials. The platform is open for people to post and rate officials in India [18].

Indonesia is ranked 96 in the Corruption Perception Index, which means it is cleaner than surrounding countries, such as Myanmar, Laos, Cambodia and Afghanistan. And parallel to other countries such as Brazil, Colombia, Panama, Peru and Thailand [19]. To minimize the level of corruption, the Indonesian government has made many efforts by developing many regulations. Indonesia is also known as a 'regulated country' in three leading institutions promoting anti-corruption programs. These include the Indonesian Corruption Eradication Commission (KPK), Indonesia Corruption Watch, and Transparency International Indonesia. The Indonesian government and other regulatory authorities are committed to fighting anti-corruption and bribery[20].

Awareness of the bad effects of corruption culture is still a major focus in the world. Special attention is needed to prevent and handle corruption cases [21]. Eradicating corruption is one of the most critical governance and development challenges [22]. The education sector is expected to be able to prevent and break the cultural chain of corruption [23]. Higher education levels must be able to reduce the level of corruption in a country. Individuals with a higher level of education tend to be more committed to civil liberties and less tolerant of government oppression [24].
One of the efforts in preventing corruption is by planting anti-corruption education culture in the younger generation through teaching materials in schools [25]. The value of anti-corruption characters is important to be built through education, which is inserted in teaching materials to be integrated in the younger generation [26]. The younger generation needs more intensive guidance and direction to become reliable human resources to protect themselves and become anti-corruption because the younger generation is part of the most important agents of change in the fight against corruption [27].

The process of anti-corruption education is not only a medium for transferring knowledge. But it also emphasizes the formation of character, anti-corruption values and moral awareness in the fight against corruption. Anti-corruption education is also an instrument to develop learning skills in capturing configuration problems and national problems that trigger corruption, impact, prevention and resolution. The education system that participates in combating corruption is an education system that departs from simple things, such as not cheating, discipline, and others. However, until now these efforts have not been maximally successful. Teachers are more burdensome to the development of cognitive abilities and less attention to the formation of skills and character as culture [28]. Single acts of academic corruption, such as cheating on exams still occur in various educational institutions. Corruption in higher education takes more international attention. Because, it influences the world view on the integrity and credibility of related universities [29], [30].

Character education in accordance with RI Law No. 20 of 2003, is a system of integrating character values including components of knowledge, awareness or willingness, actions to implement values, both against God Almighty, ourselves, others, the environment, or nationality [31]. At the conceptual level, life values-based textbooks are an integration of the values of life and principles of education by taking into account the principles of scientific learning, core competencies and basic competencies in accordance with the national curriculum, and the rules of textbook writing. The use of education-based textbooks that have a life value significantly impacts the character development of junior high school students [32]. The non-corruption education material that is implanted needs to contain the value of anti-corruption characters such as the values of honesty, responsibility, courage, justice, openness, discipline, simplicity, hard work, and caring. The teacher's awareness of the importance of anti-corruption education materials for students is actually relatively high. However, there are still many teachers who have not made teaching materials about the importance of anti-corruption education for students, especially in social studies [33].

Social science is a branch of science that is considered capable of bridging the integration of social knowledge and citizen participation with the aim of enhancing human competence and values [34]. Social studies subjects develop an understanding of globalisation perspectives and current issues as studies with a focus on nationalistic knowledge. The meaning of social science is seen as a combination of 
several unique disciplines, such as geography, history, economics, citizenship, etc. by some experts [35]. Through social studies learning, it is expected to facilitate the process of growing anti-corruption culture in the young generation from an early age.

Various studies have examined the adverse effects of corruption [4]-[7], [9]-[11]; corruptors [12], [13], [15]; anticorruption efforts [16]-[18][21]-[24][25][26][27]; the importance of anti-corruption education [28]-[30] and the inculcation of anti-corruption values based on local characters [31]-[33]. However, these studies have not been on the use of anti-corruption education teaching materials based on local characters to build a culture of anticorruption. This research focuses on the integration of social studies subjects and anti-corruption education based on local characters to build a young generation anti-corruption culture in Surabaya.

\section{RESEARCH METHODS}

This research uses descriptive qualitative research design. Data collection techniques use documentation and questionnaires. Indicators in the trial of this teaching material are categorized using a Likert scale. Indicators of the assessment of these trials are characteristics of teaching materials, including the feasibility of content, language, presentation of teaching materials, and graphics. Then, it was translated through a questionnaire with an interval value in percent form as follows: 0-19,9 = Very Poor; 20-39.9 = not good; 40-59,9 = Good enough; 60-79,9 = Good; 80-100 = Very Good. The value interval in the questionnaire was used to understand the suitability of local culture-based anticorruption education materials on social science subjects (IPS) for the younger generation in Surabaya. The population in this study were all junior high school social studies teachers in the city of Surabaya. Then choose a representative sample. Social studies teacher who teaches in class VII, VIII. IX, taking into account the geographical location, namely Central Surabaya, South Surabaya, North Surabaya, West Surabaya, and East Surabaya.

\section{RESULTS AND DISCUSSION}

Anti Corruption Education (PAK) Anti-corruption Teaching Materials Based on Local Character in Social Sciences (IPS) Subject to Building Anti-Corruption Culture has characteristics including content feasibility, linguistics, presentation of teaching materials, and graphics. Before being widely used, teaching materials that have been compiled need to be tested to determine their quality and feasibility. Then, improvements are made so that the teaching material can function effectively. In detail the results of the trials of teaching materials are as follows;

\section{A. Test of Teaching Materials}

Indicators whose assessments consist of the feasibility of the content, linguistics, presentation of teaching materials, and graphics. The results of trials carried out teaching materials which can be seen in Table I.

Table I. Test Results of Anti-Corruption Material Development (SIR) Local Character Based on The Subjects of Social Sciences (IPS) to Build a Culture of Corruption for Young People in Surabaya

\begin{tabular}{|l|c|c|c|c|}
\hline \multirow{2}{*}{$\begin{array}{l}\text { Education } \\
\text { al Testing }\end{array}$} & $\begin{array}{c}\text { Feasibility } \\
\text { Content } \\
\text { (\%) }\end{array}$ & $\begin{array}{c}\text { Linguistic } \\
\text { (\%) }\end{array}$ & $\begin{array}{c}\text { Presentati } \\
\text { on (\%) }\end{array}$ & $\begin{array}{c}\text { Kegrafisa } \\
\text { n (\%) }\end{array}$ \\
\hline $\begin{array}{l}\text { North } \\
\text { Surabaya } \\
\text { (SMPN 07) }\end{array}$ & 90 & 96 & 96 & 95 \\
\hline $\begin{array}{l}\text { Surabaya } \\
\text { East } \\
\text { (SMPN 60) }\end{array}$ & 97 & 96 & 96 & 95 \\
\hline $\begin{array}{l}\text { South } \\
\text { Surabaya } \\
\text { (SMPN 57) }\end{array}$ & 97 & 90 & 96 & 96 \\
\hline $\begin{array}{l}\text { Surabaya } \\
\text { Barat } \\
\text { (SMPN 43) }\end{array}$ & 93 & 90 & 92 & 96 \\
\hline $\begin{array}{l}\text { Central } \\
\text { Surabaya } \\
\text { (SMPN 03) }\end{array}$ & 97 & 95 & 96 & 96 \\
\hline Total & 474 & 467 & 476 & 478 \\
\hline Average & 95 & 93 & 95 & 96 \\
\hline $\begin{array}{l}\text { Average } \\
\text { Total }\end{array}$ & & 95 & \\
\hline Source: Pring| \\
\hline
\end{tabular}

Source: Primary Data processed

Based on table I above can be analyzed with details as following:

1) Feasibility Fill in

Feasibility of teaching materials developed from 6 (six) sample schools was obtained by a percentage of $95 \%$, which included an interval of $80-100 \%$ with conversion of the Very Good category. Very Good Category The point is, based on this percentage shows the material teaching materials can improve students' understanding of corruption and anticorruption efforts. The material of teaching materials has been in accordance with the needs of students, has the correctness of the substance of the material, broadens the knowledge of students, and has been in accordance with social values and morality, especially those relating to local characters.

Broadly speaking, the trial of the feasibility of the content of teaching materials shows that there is a significant suitability in the material presented. Feasibility of the content contained in the material of teaching materials can be used as a reference for teachers to foster a culture of anti-corruption for young people in Surabaya.

2) Linguistic

Anti-corruption teaching materials developed from the linguistic aspect get a percentage of $93 \%$. Includes an interval of $80-100 \%$ with the conversion category Very Good. This value indicates that the level of legibility and clarity of information is good. The choice of words and sentences is in accordance with the EYD and Indonesian language rules. The use of language and diction has been carried out effectively and efficiently. The choice of simple language facilitates understanding of the material, and avoids confusion or multiple interpretations. 
Presented that some teachers have difficulty understanding the material. Therefore, it is necessary to adjust the use of language with the cognitive level of users in this case junior high school students.

In general, the trial of linguistic elements of teaching materials shows that there is a conformity with the prevailing rules and can be used as a reference for teachers to foster a culture of anticorruption for the younger generation in Surabaya.

\section{3) Presentation of Teaching Materials}

Related to the presentation of teaching materials the percentage obtained is $95 \%$. This percentage includes the interval $80-100 \%$ with the conversion category Very Good. The instructional material developed has clear objectives, the presentation of material is made in a coherent manner, and also has the completeness in terms of information, such as reference sources. It was found that there was still a lack of good motivation in the form of pictures and words in teaching materials. In addition, the limitations of interactivity (stimulus-response) that can be applied by the teacher in learning also still need to appear again.

In general, the trial of the elements of presentation of teaching materials shows that there is significant compliance and completeness. So that the presented teaching materials can be used as a reference for teachers to foster a culture of anti-corruption for the younger generation in Surabaya.

\section{4) Integrity}

Assessment of the graphic content of teaching materials is obtained by a percentage of $96 \%$. This percentage includes the interval $80-100 \%$ with the conversion category Very Good. The use of fonts and layout of teaching materials has been considered good, as well as illustrations, graphics, images, and photographs, and display designs. However, layout arrangement, addition of illustrations, both graphics and images, still need to be refined to be even more interesting. So that it will make the design of teaching materials more interesting and additional illustrations will help facilitate the material to be understood by its readers.

The various elements that have been analyzed can be concluded that in the element of feasibility the content contains material that is in accordance with the needs of students, and is able to improve students' mastery of material about corruption. In the linguistic element, it is able to be further developed by using words that are easily understood by students. Presentation of instructional materials, has been completed, but is still able to be improved again in packaging to add motivation and interactivity to make learning more active. Based on the elements of graphics, the appearance is good, the design of colorful and attractive teaching materials will be better able to stimulate students' interest and motivation to learn.
The average value of appropriateness and suitability of teaching materials is $95 \%$. That is, the development of teaching materials for anti-corruption education (PAK) based on local characters in the subjects of Social Sciences (IPS) can be said to have good merit. Because, instructional materials are designed to increase students' understanding of corruption and anti-corruption efforts. So it is indicated to be able to build a culture of anticorruption for the younger generation in Surabaya.

\section{CONCLUSION}

Based on the analysis presented, it can be concluded that the results of the trial $(95 \%)$ of teaching materials consisting of content feasibility, linguistic, presentation of teaching materials, and graphics have feasibility in the category of Very Good / interesting / appropriate / effective. So it is indicated that it can be used as a learning resource for anti-corruption education in the younger generation in Surabaya. Teaching materials developed can be used as a teacher's guidance to guide and direct students to have an understanding of anti-corruption. Local character values integrated with social studies subjects are expected to foster a culture of anticorruption. Anti-corruption culture can be internalized in students if given through the learning process by using teaching materials based on local characters by teachers.

\section{ACKNOWLEDGMENT}

Thanks to the Directorate of Research and Community Service, the Ministry of Research and Technology of Higher Education for supporting this study through the National Strategic Research Scheme Year 2018, the Work Order No. 000001.79 / UN38.11-P / LT / 2018 on $13^{\text {rd }}$ February 2018.

\section{REFERENCES}

[1] RI Rotberg, CoRRuptIon, Global SECuRIty, and WoRld oRdER. 2011.

[2] M. Agerberg, "The Curse of Knowledge? Education, Corruption, and Politics, " Polit. Behav., 2018.

[3] S. Saha and R. Gounder, "Corruption and economic development nexus: Variations across income levels in a non-linear framework," Econ. Model., vol. 31, no. 1, pp. 70-79, 2013.

WS Lee and C. Guven, "Engaging in corruption: The influence of cultural values and contagion effects at the microlevel," J. Econ. Psychol., vol. 39, pp. 287-300, 2013.

[5] A. Farooq, M. Shahbaz, M. Arouri, and F. Teulon, "Does corruption impede economic growth in Pakistan ?," Econ. Model., vol. 35 , pp. 622-633, 2013.

[6] O. Borcan, M. Lindahl, and A. Mitrut, "The impact of unexpected cuts on corruption: Evidence from a," J. Public Econ., vol. 120, pp. 32-47, 2014.

[7] J. Coles, A. Lee, A. Taft, D. Mazza, and D. Loxton, "Childhood Sexual Abuse and Its Association With Adult Physical and Mental Health: Results From a National Cohort of Young Australian Women, " J. Interpers. Violence, vol. 30, no. 11, pp. 1929-1944, 2015.

[8] M. Birney, "Decentralization and Veiled Corruption under China's 'Rule of Mandates,"' World Dev., vol. 53, pp. 55-67, 2014. 
[9] J. Bologna, "The effect of informal employment and corruption on income levels in Brazil," J. Comp. Econ., vol. 44, no. 3, pp. 657-695, 2016

[10] G. Beekman, E. Bulte, and E. Nillesen, "Corruption, investments and contributions to public goods: Experimental evidence from rural Liberia," J. Public Econ., vol. 115, pp. 37-47, 2014.

[11] S. Seebacher and R. Schuritz, "Blockchain Technology as an Enabler of Service Systems: A Structured Literature Review," in Proceedings International Conference on Exploring Services Science, 2017, vol. 0, no. March 2018, pp. 12-23.

[12] G. Beekman, EH Bulte, and EEM Nillesen, "European Journal of Political Economy Corruption and economic activity: Micro level evidence from rural Liberia," Eur. J. Polit. Econ., vol. 30, pp. 70 79, 2013.

[13] T. Kunieda, K. Okada, and A. Shibata, "Corruption, capital accounts liberalization, and economic growth: theory and evidence," Int. Econ., vol. 139, pp. 80-108, 2014.

[14] CJ Huang, "Is corruption bad for economic growth? Evidence from Asia-Pacific countries, "North Am. J. Econ. Financ., vol. 35 , no. 100 , pp. $247-256,2016$

[15] H. Li, H. Xiao, and T. Gong, "The impact of economic well-being on perceptions of anti-corruption performance: Evidence from China," Policy Soc., vol. 34, no. 2, pp. 97-109, 2015.

[16] A. Graycar, "ScienceDirect Corruption: Classification and analysis," Policy Soc., pp. 1-10, 2015.

[17] M. Holtzblatt and N. Tschakert, "Baker Hughes: Greasing the wheels in Kazakhstan (FCPA violations and implementation of a corporate ethics and anti-corruption compliance program)," $J$. Account. Educ., vol. 32, no. 1, pp. 36-60, 2014.

[18] D. Ryvkin, D. Serra, and J. Tremewan, "I paid a bribe: An experiment on information sharing and extortionary corruption," Eur. Econ. Rev., vol. 94, pp. 1-22, 2017.

[19] Transparency International, "Transparency International corruption perceptions index 2017," Transparence. Int. Corrupt. perceptions index 2017, p. 12, 2017.

[20] C. Joseph Joseph, J. Gunawan, Y. Sawani, M. Rahmat, J. Avelind Noyem, and F. Darus, "A comparative study of anti-corruption practice disclosure among Malaysian and Indonesian Corporate Social Responsibility (CSR) best practice companies, " J. Clean. Prod., vol. 112, pp. 2896-2906, 2016.

[21] LD Carson and MM Prado, "Using multiplicity institutional to address corruption as a collective action problem: Lessons from the Brazilian case," Q. Rev. Econ. Financ., vol. 62, pp. 56-65, 2016
KR Hope, "Erratum to: The Corruption Problem in Swaziland: Consequences and Some Aspects of Policy to Combat It, (2016), 32, (130-158), 10.1177 / 0169796X15609715), " J. Dev. Soc., vol.
32, no. 3, p. 323, 2016.

[23] J. Godemann, J. Haertle, C. Herzig, and J. Moon, "United Nations supported Principles for Responsible Management Education: Purpose, progress and prospects," J. Clean. Prod., vol. 62, pp. 16-23, 2014.

[24] R. Truex, "Corruption, Attitudes, and Education: Evidence from Nepal Survey," World Dev., vol. 39, no. 7, pp. 1133-1142, 2011.

[25] Sarmini, T. Suyanto, and U. Nadiroh, "Analysis of teaching materials of civic education is characterized by the value of character in building anti-corruption culture Analysis of teaching materials of civic education is characterized by the value of character in building an anti-corruptio, "J. Phys. Conf. Ser., vol. 953, pp. 1-4, 2018.

[26] Sarmini, I. Made Swanda, and U. Nadiroh, "The importance of anti-corruption education teaching materials for young generation," J. Phys. Conf. Ser., vol. 953, no. 1, 2018.

[27] SO Sihombing, "Youth perceptions toward corruption and integrity: Indonesian context," Kasetsart J. Soc. Sci., pp. 1-6, 2018.

[28] P. Widiatmaka, "Constraints on Citizenship Education in Building Character of Students in the Process," J. Civ., vol. 13, p. $\mathrm{xxx}, 2016$.

[29] DW Chapman and S. Lindner, "Degrees of integrity: the threat of corruption in higher education," Stud. High. Educ., vol. 41, no. 2, pp. 247-268, 2016.

[30] WG Tierney and NS Sabharwal, "Academic corruption: Culture and trust in Indian higher education," Int. J. Educ. Dev., vol. 55, no. May, pp. 30-40, 2017

[31] N. Indawati, "The Development of Anti-Corruption Education Course for Primary School Teacher Education Students," J. Educ. Pract., vol. 6, no. 35, pp. 48-54, 2015.

[32] K. Komalasari and D. Saripudin, "The Influence of Living Values Education-Based Civic Education Textbook on Student's Character Formation," Int. J. Instr., vol. 11, no. 1, pp. 395-410, 2018.

[33] S. Sulistyawati and N. Purba, "Anti Corruption Education Through Characters Building Value," Humanit Journals. Soc. Sci., vol. 22, no. 1, pp. 7-11, 2017.

[34] T. Misco, "'It is definitely the priority': A postcolonial inquiry into social studies education in the Commonwealth of the Northern Mariana Islands," J. Soc. Stud. Res., vol. xx, no. xx, p. $\mathrm{xx}, 2017$.

[35] AJ Castro and RT Knowles, Social Studies Education, Second Edition., vol. 22. Elsevier, 2015. 